\title{
Crafting citizen(ship) for people with dementia: How policy narratives at national level in Sweden informed politics of time from 1975 to 2013
}

Ann-Charlotte Nedlund and Jonas Nordh

\section{Linköping University Post Print}

\section{Tweet}

N.B.: When citing this work, cite the original article.

Original Publication:

Ann-Charlotte Nedlund and Jonas Nordh, Crafting citizen(ship) for people with dementia: How policy narratives at national level in Sweden informed politics of time from 1975 to 2013, 2015, Journal of Aging Studies, (34), 123-133.

http://dx.doi.org/10.1016/j.jaging.2015.06.003

Copyright: Elsevier

http://www.elsevier.com/

Postprint available at: Linköping University Electronic Press

http://urn.kb.se/resolve?urn=urn:nbn:se:liu:diva-120866 


\title{
Crafting citizen(ship) for people with dementia: How policy narratives at national level in Sweden informed politics of time from 1975 to 2013
}

Keywords:

Dementia; Citizenship; Policy narratives; Policy-making; Social construction; Sweden

\begin{abstract}
This article explores how policy narratives in national policy documents in Sweden inform associated politics on people with dementia. This is disentangled in terms of how people with dementia have been defined, what the problems and their imminent solutions have been, and if and how these have differed over time. Based on a textual analysis of policy documents at national level in Sweden, covering nearly 40 years the study shows how divergent policy narratives shape the construction of citizens with dementia as policy target groups. This study shows the temporal character of people with dementia as a political problem, the implications of policy narratives on people with dementia as a citizen group, and policy narratives as something being crafted rather than shaped by fixed pre-existing "facts". Dementia, and further citizens living with dementia, does not have a once and for all stabilised meaning. Instead, the meanings behind the categories continue to evolve and to be crafted, which affects the construction of citizens living with dementia, the space in which to exercise their citizenship and further belonging to the society.
\end{abstract}

\section{Introduction}

This article focuses on how policy narratives in national policy documents in Sweden inform associated politics and further the space within which people with dementia can exercise their citizenship. Utilising a citizenship perspective in order to study and problematize situations for people living with dementia, has received increasing attention during the last decade. Significant 
interest followed Bartlett and O'Connor's article (2007), where they presented their ideas of using a "citizenship lens" to gain a more appropriate understanding into dementia research, by recognising a person living with dementia as an active agent with the right to be selfdeterminant, formulate their own goals and have power over their own lives. In dementia research, the citizenship lens is in contrast to the two dominant perspectives: the biomedical lens (cf. Ballenger 2006), where people with dementia are depicted as "sufferers" with substantial care needs, the solution to which is finding medical treatment in order to cure or ease the medical condition, and to the personhood lens, where dementia is regarded as a unique personal experience of living with dementia dependent on unique biopsychosocial factors (cf. Kitwood 1997).

An increasing body of research problematize citizenship and social exclusion of people with dementia, due to an existing understanding within their surroundings that they are incapable of participating in social interactions (Brannelly 2011; Gilmour \& Brannelly 2009; Behuniak 2010, 2011; Baldwin 2008; Kelly and Innes 2013). Other studies shed light on citizenship from a legal perspective related to aspects of self-determination (Boyle 2008; 2010; 2011; 2013). Another type of problematisation is how citizenship can be practised through self-help groups, the ombudsman and by people living with dementia as active co-researchers (Bartlett 2012; Örulv 2012). Studies have also problematized the institutional meetings between care managers and people with dementia from a citizenship perspective (Taghizadeh Larsson \& Österholm 2014; Österholm \& Hydén 2014; Österholm \& Samuelsson 2013). However, there are still few studies that seek to problematize the role of national policies in order to increase the understanding of how policy narratives have constructed people with dementia as policy targets and service users, and the further implications on claiming citizenship. Baldwin (2013) touched upon it by analysing the narrative features of the UK's National Dementia Strategy (NDS) and its related documents. His analysis shows the persuading character of national policy documents with a dominant and univocal view of dementia within a narrative medical model, although the voices of several diverse stakeholders had been incorporated. As Baldwin concludes, "the NDS opened 
up space for stories to be told about certain aspects of dementia and closed down opportunities for other stories." (Baldwin 2013:82).

Collective narratives are powerful, they can influence the "assumptive worlds" that service providers convey into their professional/occupational tasks (Wilson 1991). Thus, by identifying dominant stories as well as excluded voices, the study of policy narratives gives us some information on how and whether people with dementia can practice their citizenship. The present article attempts to bridge this knowledge gap.

The purpose of the present paper is to explore how policy narratives in national policy documents in Sweden inform associated politics on people with dementia. This is disentangled in terms of how people with dementia have been defined, what the problems and their imminent solutions have been, and if and how these have differed over time. The study is based on a textual analysis of policy documents at national level in Sweden, covering nearly 40 years. The study contributes to the theoretical debate on the dynamic process and the temporal character in handling a political problem, the implications of policy narratives, and further how the ambivalent framing affects the construction of citizens, the citizenship content and space within which people with dementia can exercise their citizenship.

\section{Understanding citizenship as shaped by policy narratives}

Citizenship is commonly referred to as an agreement between the citizens and welfare authorities that typically include civil, political and social citizenship rights, as well as duties (Marshall1991/1950). However this view has been contested where citizenship also encompasses dimensions, such as how people experience themselves in collective and cultural terms, and highlights dimensions such as identity, solidarity with others, social membership, belonging, the politics of recognition and by being a political actor in a community (Bosniak 2006; Lister 2003; Kymlicka 2002; Isin 2002, Yuval-Davies \& Werbner 1999). In this way, citizenship concerns the relationship between the state and the citizen, the relationship between citizens, but also the 
meaning of belonging and the practice of political enactment in claiming rights in society, including its various policy areas.

The meaning of citizenship and the construction of citizens are constantly under negotiation and interpretation, and therefore undergoing change. Public policies are primarily means whereby government can influentially institutionalise, legitimise and change social constructions of citizenship and citizens (Schneider \& Ingram, 1997 1993a, b; Hajer 1993). The policy process relates to the construction of political problems where the construction of policy areas, targeted groups, goals and appropriate solutions do not come into being until they are recognized as political problems. Policies are not mirrors of reality; rather they create meaning and give a specific question a particular value (Bacchi 2009). The process in which problems and their imminent solutions become recognized and thereby legitimate, is a struggle over ideas and interests where various actors compete (Stone 2002).

An important element in this process is policy narrative. Policy narrative is a powerful tool used to shape beliefs and actions (Roe 1994; Jones \& McBeth 2010; Jones et al 2014). Policy narratives rest on particular understandings of causes, dynamics and knowledge claims about problems, and a means to present reality in such a way that it becomes a more coherent whole than is possible in practice. What can be considered a problem will depend on the narrative in which the problem is debated. Hence, narratives drastically simplify the phenomenon they are seeking to steer (Boswell et al 2011). The presentation of narratives is often in order to see problems as facts, as originating from natural forces even though they do not need to be factual to a full extent, or at all. By doing so, the problem and its solution are more likely to be accepted and thereby close the debate. They contain "causal stories" which construct causality portraying the evolution and causes of the problem, including its imminent solution, in ways that are comprehensive and convincing (Stone 1989). In this way narratives offer reasons for requisite acting in certain situations and serve to legitimize a particular political course of action (Roe 1994; Hajer 1993; Waagenar 2011). The narrative in which a problem is presented will also draw on former or existing solutions to similar problems (Hajer 1993; Atkinson 2000). In that sense, 
policy narratives are underwriting and stabilising the assumptions in the policy process (Roe 1994). A story is dominating when it directs policies, institutional action and important policy actors (Stone 1989; Hajer 1993; Boswell et al 2011). Commonly, there can be several competing policy narratives for understanding, in which many actors vie for control. Policy narratives are not a uniform whole; they can encompass various persuasive arguments and elements of discourse and take place on many different levels and localities, but are held together by a similar conceptualisation of the world (Hajer 1993). According to Schön and Rein (1994) these underlying structures of belief, perception and appreciation that construct policy problems and preferred solutions, can be understood as problem frames. In ambiguous and complex situations, actors create narratives of social reality through a complementary process of framing. Usually the identification and framing of social issues in public policies and practices are related to which actors claim, or are claimed to have knowledge (Colebatch 2009; Schneider \& Ingram 1993a, b; Stone 2002; Fisher 2009).

Policies and their narratives can be regarded as "political persuasions" (Atkinson 2000); they are dynamic instruments where the state gives signals and legitimises how citizen groups are valued and regarded by other citizens, which attitudes and courses of action are regarded as appropriate and what services they can expect from welfare organisations (Schneider \& Ingram 1993b; Stone 2002). Welfare-state organisations can either support or undermine established images of various citizen groups, but also call attention to former disfavoured citizens, and create new categories of citizens. The definition and construction of various categories of citizens are seldom explicit, but often imbedded in policies. As stressed by Yuval-Davis (2011), citizenship is always constructed in intersecting social divisions. Citizens and citizen groups always involve "concrete" people that are differentially situated in terms of gender, class, ethnicity, sexuality, ability, state in the life cycle, etc. Henceforth, policies position different groups in different ways, assigning them values by constructing certain groups and behaviours as problems. The belonging of a specific target group will affect the distribution of rights/entitlements and obligations, i.e., what the citizenship content will be. Nevertheless, the social construction of targets is necessary for making policies politically and practically feasible. 
Policy narratives and the construction of policy targets is dependent on which actors are involved in the policy process and, to be more specific, have the power to get involved or to be considered (Schneider \& Ingram 1993a, b; Stone 2002; Yuval-Davis \& Werbner 1999; Lister 2003). How political problems are constructed and re-constructed is dependent on who participates in the process and which actors claim, or are claimed to have knowledge (Colebatch 2009; Schneider \& Ingram 1993a; Stone 2002). Policy narratives not only inform citizens if they are regarded as important, but they also empower citizens who have the skills to solve problems in a particular narrative framework. Therefore, in order to be able to influence the content of citizenship, citizens need to have access to the processes in which the citizenship is constructed. In this relation, policies construct citizens in terms of policy targets which may have negative implications for their citizenship and, in the long run, the democracy (Yuval-Davis \& Werbner 1999; Schneider \& Ingram 1993b; Fischer 2009). Moreover, the shift in who does or does not become a policy target is often related to the practical work and the temporal character of political problems. Though policy resistance is more common than policy change (Schneider \& Ingram 2005). Hence, by studying policy narratives we can shed light on the power of stories that in the end create citizenship for people with dementia.

Drawing on the theoretical perspectives outlined above, we will identify the policy narratives related to people with dementia and what implication this could have on their citizenship content.

\section{People with dementia as a policy issue}

In several countries the issue of people with dementia has recently gained more attention on the political agenda (cf. G8 UK 2013). One reason behind this is that the number of people with dementia is increasing due to demographical changes as well as due to better diagnoses, where more people receive a diagnosis at an earlier stage of life. It is estimated that the number of people with dementia in the world will increase from 35.6 million in 2010 to 115.4 million in 2050. This increase will cause strain on public resources, as for example in the UK where the 
societal cost of dementia exceeds that of stroke, cancer and heart disease combined (Alzheimer's Disease International 2012). In Sweden approximately 160,000 people have dementia, this number will increase (NBHW 2014).

Dementia is a condition of symptoms comprising disturbances in cognitive, communicative, behavioural and emotional functions. Abilities are affected usually resulting in failing memory, difficulties in planning and carrying out everyday tasks and orientating oneself in time and space as well as problems with language and communication (cf. Örulv 2010; Hydén 2014). There are various diseases behind dementia: Alzheimer's disease, vascular dementia, stroke, Parkinson's and Lewy-Body dementia (Gaunt et al 1993). What is clear is that this medical view of dementia has overshadowed the individuals living with dementia, focusing mostly on a biomedical view of the disease. Other things such as identity, self and relationships towards, for example, spouse, family and friends are also affected by a dementia diagnosis (Innes 2009). Hence, dementia not only affects physical or psychological factors, but also social factors in the interactions of individuals and their relationship to others. Commonly, differences in background such as class, gender, ethnicity, culture, etc. are not considered when dementia is the case. Consequently, people with a dementia diagnosis and their relatives, constitute a heterogeneous group often overlooked, not least when it comes to the provision of care (Innes 2009). Therefore, as the number of people living with early symptoms of cognitive failure, or suffering early or mid-stage dementia increases, it is relevant to regard it not only as a progressive brain disease, but also to understand the social aspects of dementia, i.e., how people with dementia live and cope with their illness (Hydén \& Örulv 2009). Moreover, there are wider implications in terms of the rights of the person with dementia, e.g., the right to make decisions about where to live, about care and ultimately about political issues (cf. Kelly \& Innes 2013; Baldwin 2008; Österholm \& Hydén 2014), and further, in terms of belonging to a society and being regarded as a citizen.

\section{Methods}


This study followed an interpretive research approach (Yanow 1995; 2000) based on a qualitative textual analysis of national level policy documents in Sweden, such as those from the Government and Parliament Offices, the National Board of Health and Welfare (NBHW), and the Swedish Association of Local Authorities and Regions (SALAR) over the period 1975 to 2013. The search strategy and selection of policy documents was broad and covered differing policy areas, since people with dementia, both explicitly but many times implicitly, are to be found in various policy areas. In our search strategy we also contacted staff working in the archives at the NBHW and The National Archive in Sweden. Though their lists of material confirmed the documents that we had already identified. To clarify, when selecting documents, the criterion was not that people with dementia had to be an explicit target group, but that the policies could cover people who had dementia, particularly in the early documents. This also marked our starting point, 1975, since people with dementia started to become visible in the documents at the end of the1970s. In total, 165 documents were identified (a list is available upon request) comprising mainly investigations and reports, but also political proposals or changes to existing laws.

By having an interpretive approach our focus, as guided by Yanow (1995: 111-112), was on "meaning created, conveyed and interpreted in specific situations as well as on the processes by which these meanings are made". The documents were not narratives but can be understood narratively (Baldwin 2013) and as "policy-as-discourse" (Bacchi 2000). The analysis was an iterative process exploring both horizontally across text and longitudinally through time. Since interpretations are not only the subject of study but also the method of investigation (Yanow 1995), the documents were carefully read in order to find views and framings, including their constructed problems and suggested solutions related to people with dementia, which revealed different narratives. Following Rein and Schön (1994), each policy narrative constructs a different view of social reality, selecting different features and relations through a process of framing. These problem frames determine what facts are "true" and what arguments are relevant. By doing this we were making sense of the stories and non-stories, whereby we then identified policy narratives (cf. Hajer 1993; Wagenaar 2011; Stone 2002; Roe 1994). Rather than only 
asking what the problem is, we also asked "how" and "why" in order to understand their meaning and establish what stories diverge from, or run counter to the dominant policy story, and reflect on "what is not" (Roe 1994; Atkinson2000; Yanow 2000; Fischer 2003). We were also interested in the way narratives conflict, e.g. if they were polyphonic, containing stories from several stakeholders and/or "univocal" in giving a singular perception of a social problem (Baldwin 2013). Following this approach we could identify four episodes with shifting dominant policy narratives and on some occasions also competing stories. In the text, we use the term "narrative" interchangeably with "story". Also, expressions in the four episodes represent the temporary construction that we found in the documents, i.e. they are not our personal expressions. In order to make this clearer we have marked them in citation marks.

The findings will be presented through identified episodes and eventually we summarize and compare shared assumptions and differences based on the narratives. The episodes and narratives are kept brief; they do not claim to reflect reality or reconstruct episodes and narratives fully. However, they shed light on major policy narratives related to people with dementia and the posed imminent solutions.

\section{Findings}

In this section four episodes are presented which cover identified policy narratives (see Figure 1). Though the narratives overlap, they influence subsequent narratives where parts of narratives could be presented in parallel, the shifts are not absolute. 


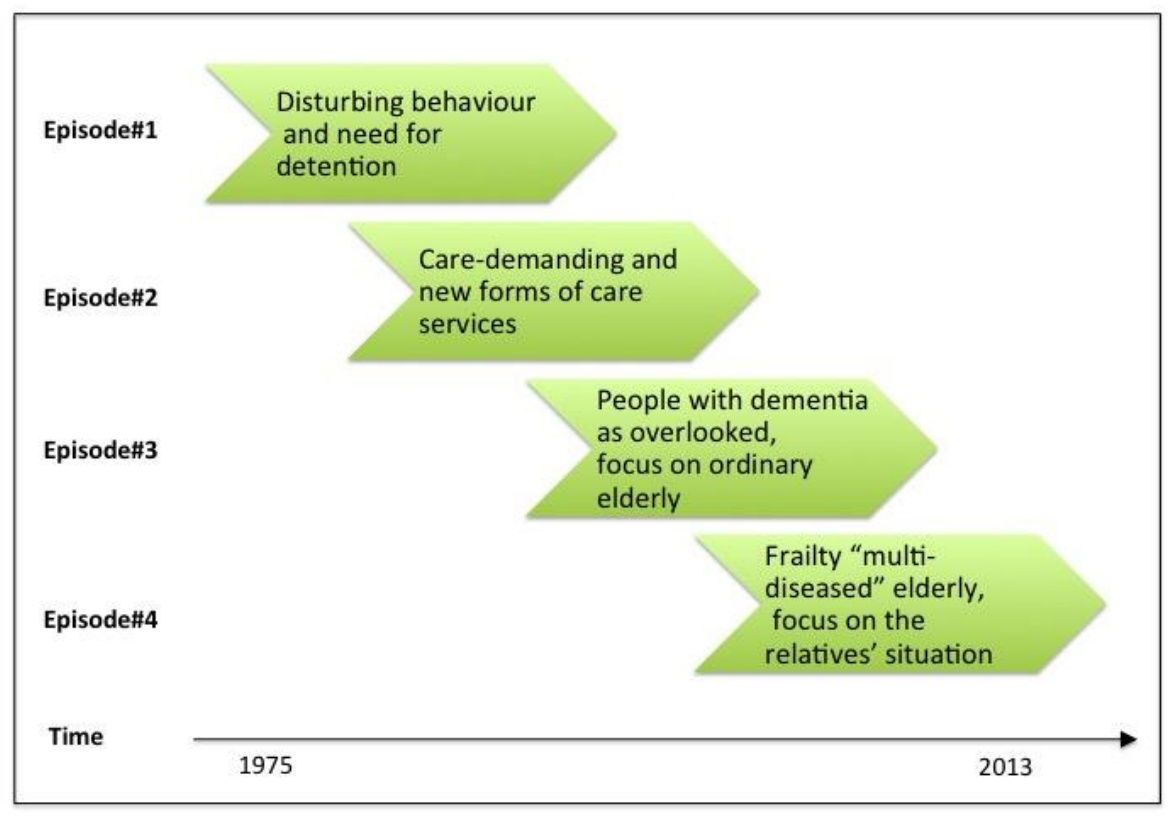

Figure 1: Episodes and policy narratives relating to people with dementia identified in the studied documents. The shades illustrate that the policy narratives overlap

\section{Episode \#1: Disturbing behaviour and need for detention}

During the 1960s and 1970s, there was a substantial increase in nursing homes and long-term hospital care. Hence until well into the late 1970s, the major part of care for elderly and sick people was handled within the publically funded welfare system.

At this time the narratives that held sway were that people with dementia were either (a) considered as "forgetful elderly" and thus their behaviour was regarded in terms of a normal consequence of ageing and within a model of ageism or (b) considered as "mentally deranged" in cases of more severe states of dementia where their behaviour, in contrast to the former view, was regarded in terms of illness and thus within a medical model. As this was held true, the solutions for handling people with dementia differed; those who were regarded as "normal elderly" were included within "ordinary elderly" care such as for example, home services and 
nursing homes. The major part of those who had moderate or severe dementia lived in institutions such as nursing homes and mental hospitals. Overall, "dementia” was rarely mentioned in policy documents during this period.

At the end of the 1970s and the early 1980s, a new story was emerging that highlighted the critical situation for "ordinary forgetful elderly." An event coming from this narrative was the Social Services Act, enacted in 1982, where the provision of social-care services for the elderly, disabled, etc. became an obligation for the local authorities. Two explicit goals for care of the elderly were emphasised: "self-determination", the elderly's right to actively participate in the forming of elderly care, and "normalisation" to facilitate life in an ordinary environment for the elderly. Within this narrative the situations of people with dementia received more attention. A few documents also have "elderly demented" in the title, which implied that these people started to be more frequently categorized as a group of their own and regarded as a policy target. Though this emerging story was still marginal, many documents referred to speeches at symposiums where only a few enthusiastic stakeholders participated. Commonly, the stories covered other actors' attitudes toward people with dementia. A quote by one director at the NBHW, who was referring to this episode, substantiates a negative conceptualisation by saying 'we could really with reason ask the question 'who loves a demented?' and the answer was that no one really does" (NBHW 1985). The narratives of "elderly demented" and "demented patients" were clearly negative; people with dementia had "problematic behaviour", were framed for example as "a burden"; "a social-environmental destroyer"; annoying for other patients, staff, and relatives; uninteresting; and cost-demanding. Even though the negative framing to a large extent held sway, it slightly diverged in the new narrative where there was an attempt to nuance the view of people with dementia, often based on a normative belief related to deservedness, e.g., that the elderly had paid taxes during their working-life and deserved to be treated with dignity despite their memory having failed. Hence, the public welfare system had to take care of "elderly demented" somewhere, where they did not disturb others. 
Moreover, in this narrative, an emerging idea as an appropriate solution to improve and prevent “disturbing elderly-demented behaviour" was a better housing environment. An awareness emerged that existing care and home facilities for the elderly in general were not adequate. This awareness emanated from the great de-institutionalisation of psychiatric care in Sweden, in the late 1970s and 1980s, where it literally became apparent that a great number of "demented people" resided in mental hospitals. A case mentioned was that of one county council where $74 \%$ of the patients (65 years and over) at the mental hospital had dementia (IPRHS et al 1978). As a consequence, the NBHW (1980) decided in their guidelines for 1980s psychiatric care, that people with symptoms of dementia who needed long-term institutional care should be taken care of within somatic long-term care and not in mental hospitals. Henceforth, people with dementia were no longer categorised as targets for mental institutions. It subsequently became clear however that this emerging course of action could not be followed through; the quantity of places in somatic long-term care was not sufficient for all. As a consequence, the solution for dealing with this problem followed the dominant mode of rationality, i.e. keep people with dementia within psychiatric care.

The question of where to place the elderly and people with dementia became a debated puzzle. An emerging awareness in this narrative was that the role of the relatives was not sufficiently visible. Therefore, an ambition was to reduce the tendencies that the elderly would be too dependent on the support of the welfare state. The reasons behind this were explained as twofold: both "human" reasons, since it was considered better for people with dementia to be with relatives, and "cost-driven" reasons, since the sheltering of people with dementia, and the elderly in general, was too cost demanding. Accordingly, there was a quest for new caring options. As a policy problem, people with dementia were conceptualised in a medical model and in terms of being "disturbing" and deviant. The notion of action was still within the responsibility of the welfare state even if the role of relatives emerged as an alternative solution. Thus, in the narratives within this episode people with dementia were entitled to citizenship. They had for example paid taxes and it was regarded as the welfare state's responsibility to find solutions. This shed light on the solidarity aspect of citizenship and the fact that they socially 
belonged to the community. However they were clearly disempowered as a group of citizens, and the framing of this group was negative, just as the solidarity aspect was mentioned more in terms of placing people with dementia rather than in terms of support and other types of services. Although dementia, being a social category and thus as an identity, meant recognition for the first time as a target group for policies.

\section{Episode \#2: Care-demanding and new forms of care services}

Years before a space for a new narrative was opened up, where the notion of action was reframed in terms of organising new forms of care services for elderly in general. In 1980, the parliament set up the "Elderly Care Commission" [Äldreberedningen], to examine prioritizations and coordination of the welfare state's services for the elderly. The commission would also focus on forms of housing, social services, including home services, and health-care services for the elderly so that they could live an autonomous life. Their work became a basis for the government bill 1987/88:176 which stated that the issue of changing the responsibilities of the county councils and the municipalities was necessary in order to have a more uniform political and economic responsibility for elderly care services. Also, support of relatives by the welfare state, was brought up. In 1988 a new commission, the "Elderly delegation” [Äldredelegationen], was established which concluded the need to develop more "special-care facilities", as these would be the solutions both for people placed in institutional hospital care and for the elderly with severe health-care needs. Their conclusion resulted in a slightly re-formulated government bill “Ädelproposition”, 1990, which later became enacted into law in 1992 as one of the most comprehensive reforms in Sweden, the "Community Care Reform” [Ädelreformen](further explained in episode \#3).

Even though the dominant narrative to make the care services more uniform was targeted at the elderly in general, other partly challenging narratives emerged that focused on dementia. During the period 1984-1985 the NBHW, together with county councils and municipalities in five areas of Sweden, started up an experimental project in order to develop new forms of care facilities. These were named "special-care facilities" where each resident had their own room 
supplemented by common areas such as a kitchen, dining and living room. Also these facilities had day-care centres where "the demented" could stay during the daytime in order to ease the burden on relatives or care workers. From the outset this was not a project initiated by the state, but by a counter-narrative, which emphasised the need for structural change concerning the care of people with dementia. This counter-narrative, driven by enthusiastic stakeholders who had started "special care facilities", articulated an alternative solution, which later became more visible and accepted. These new forms of organising care for people with dementia, "the demented", which included procedures for cooperation between the respective county council and the local authority, could be tested because they were already in existence and showed that special-care facilities were possible alternatives to institutional care. Consequently, these became a role model for other areas, not only for people with dementia. In 1987, yet another governmental commission was set up to investigate what plans the local authorities had to improve the living situation for "elderly, handicapped and long-term ill people". The mind set was that a structural change was needed either to decommission or to renew the institutions involved in the care of people with dementia.

During this episode, the dominant narrative of people with dementia differed slightly from the former episode. Rather than mainly regarding them as patients, disturbing to others, impossible to care for outside institutional hospital facilities, they were now regarded as "care-demanding". Moreover, the notion of action for people with dementia became framed in terms of lack of knowledge on how to take care of this group. One clear idea was to prevent "unwanted behaviour" of people with dementia by letting them stay in a home-like environment with familiar furniture and interior decor. This also shed light on an emerging awareness that people with dementia were individuals with individual preferences. Also other social factors were starting to be taken into account, such as marital status and ethnicity. Resultantly, people with dementia started to not only be identified in terms of their disease but also in other social categories and thus to belong to other citizen groups. However, people with dementia were still conceptualised in a medical model but now in terms of being care-demanding. Thus, the notion of action focused on new forms of care services, but also on support for relatives. As before 
people with dementia were entitled to citizenship but clearly framed as a non-capable and nonactive citizen group. In other words, they were disempowered as a group of citizens and neglected in terms of acting and participating as citizens. The narratives also embraced the goal and recognition of the right to be autonomous, however this did not clearly include people with dementia but rather the elderly in general. Even though they were disempowered as a group the notion that people with dementia had differing social factors may imply that they were starting to be seen as citizens with individual situations as other citizens were although they were not able to influence this framing themselves.

\section{Episode \#3: People with dementia as overlooked, focus on ordinary elderly}

During the 1990s the whole health and social care sector was targeted for extensive reforms regulating the authorities' specific areas of responsibility, often in combination with comprehensive reorganisation and economic downsizing.

The first reform, "Community Care Reform" [Ädelreformen], enacted in 1992, was a result of former commissioned work and implied changes in both the Social Services Act (SSA) and the Health and Medical Service Act (HMSA). Responsibility for care of the elderly, people with disabilities, etc. shifted from county councils to municipalities, which now became responsible for the cost of elderly care, except when it concerned health care by medical doctors. The reform also facilitated municipalities providing health care in the users' own home. Therefore, the elderly were no longer cared for in hospitals etc. but cared for at home or at home-like institutions. This implied a shift from health care to social care. After the reform all types of institutional care were labelled "Special housing".

The two other reforms did not explicitly cover people with dementia but had an impact on narratives related to them. One was the Disability Reform [Handikappreformen], enacted in 1994, with the purpose of levelling out the differences in living conditions between people with 
disabilities and other citizens. The reform also aimed at improving the cooperation between authorities; the municipalities now became responsible for the care of people with disabilities (except rehabilitation and habilitation), and people with mental illness would be taken care of by special-care services. The reform led to changes in SSA and HMSA and was followed by a new human-rights law: the Act Concerning Support and Service for Persons with Certain Functional Impairment (ASS), which aimed at promoting equality, full participation, good living conditions, quality in support and services, and respect for self-determination for people with disabilities. The other reform, Mental Health Care Reform [Psykiatrireformen], enacted in 1995, was targeted at people with "long-term and serious mental impairments". This reform had an explicit delineation from people with dementia, stating that they were not given any specific focus as dementia was to be covered by the Community Care Reform. The new way of regarding people with disability had an impact; mental illness had to be considered from an impairment/disability perspective. These two reforms established a shift and a new approach to disability and mental illness as something that a person had, partly in relation to the society, rather than something that the person was.

At the end of this episode, the government commissioned the NBHW to monitor the development of elderly care from 1997 to 2000, this was called the "Elderly Commission" [Äldreuppdraget]. In 1998, additional changes in the SSA implied that elderly with severe needs were prioritised where others with minor needs were deferred. This shift implied a focus on caring, rather than on the social aspects of the elderly's everyday life.

Hence, these narratives show that during this episode people with dementia were covered by the elderly-care policies which had implications for them as citizens as well as for their relatives: they were overlooked and disempowered. This can be seen as neglecting them as a citizen group, focusing on targets other than people with dementia. Due to the austerity within the public sector this affected several areas. One reason for dementia to be overlooked could depend on the power of the group. Advocates for the disability movement as well as for mental illness were already established, while people with dementia as a group had recently emerged, this made them less 
powerful in influencing policy. During this episode, public resources for funding elderly care decreased at the same time as the number of elderly increased. It shows that dementia-related policies reflect changes in other welfare policies. In times of financial constraint in the welfare state, different policy areas compete, which easily allows areas that are more established to become more powerful and more influential in informing the politics of time compared to other policy areas i.e. that policies covering elderly in general, dominated at the expense of less focus on other less-established areas such as policies targeting people with dementia. The notion of action focused on public services for "frailty elderly", elderly living in a single household or with no nearby relatives, and on the role of relatives where support and incentive grants were allocated. People with dementia, by having greater needs or suffering "frailty", were entitled to citizenship, though the medical model dominated.

\section{Episode \#4: Frailty "multi-diseased" elderly and focus on the relatives' situation}

A new policy narrative started to take form at the very end of the 1990s. As a contrast to the former episodes and narratives, people with dementia started to be clearly visible and acknowledged in several national policy documents. One indicator of this shift was the concluding remark by the "Elderly Commission" [Äldreuppdraget], which stated that people with dementia were "one of the groups that had been neglected in the governmental initiative to improve elderly care, and thus needed to be highlighted" (NBHW, 2000).

In this episode, policy makers were puzzled by the categorising of people with dementia and the boundaries of other target groups. First, there was delineation between mental impairment and dementia. This boundary was referred to in the Mental Health Care Reform, in 1995, but can also be found in reports from this episode that declared that dementia should not be regarded as a mental illness if there is not another psychiatric disease. Nevertheless, people with dementia were still included within this target group because of difficulties in separating them from geropsychiatry. This boundary narrative continued during the whole episode. There was also a demarcation between disability and dementia. However people with dementia were not covered 
in disability policies unless they were under the age of 65 (ASS). Henceforth, in this boundary narrative people with dementia belonged to the category of elderly people. Another boundary narrative emphasised the "healthy elderly" and thus aimed at separating them from people who had dementia. As a consequence, people with dementia became framed as a group with complex needs who were entitled to special housing and special day-care services.

What is also clear during this episode is the change in how people with dementia were referred to, i.e., from "demented" to "people with dementia". This frame shift followed the same narratives as for people with disability and mental illness during the 1990s, highlighting the person and not the disease or impairment.

A strong emerging narrative during this episode that covered people with dementia, was highlighting the disease. It started by the use of "frailty elderly" but changed to "multi-failing elderly", "multi-diseased elderly" and later to "most-diseased elderly". The definition criteria for this category have differed, both concerning number of diseases and at what age acquired. In this narrative people with dementia were clearly delineated to a medical model emphasising comorbidity. This strong narrative was accompanied by the story of a "growing population with multiple failings and therefore also complex needs", often complemented by a public sector stressed by austerity. The increasing political importance of this group was clear, not least since a national elderly coordinator was appointed. An explicit goal in this governmental strategy, from 2011-2014, was "good quality of care in dementia". Another clear attempt to highlight the care of people with dementia was the specific national guidelines by the NBHW from 2010 [Nationella riktliner för vård och omsorg vid demensjukdom]. The government also gave incentives to the local authorities to register people with a dementia diagnosis. In other words, the dominant narrative was strongly influenced by a medical model.

In this episode there are narratives framed within "person-centred care" that cover the difficulties in having the disease. However, commonly this story is presented through the perspective of others, such as the relatives, rather than from the person him/herself. In numerous reports, 
dementia was referred to as the "the disease of the relatives". Hence, relatives of people with dementia were accorded a greater importance, as people, as carers and further as citizens. There is still, in accordance with the former episode, a strong focus on the elderly and people with dementia staying at home as long as possible (NBHW, 2005).

A partly divergent narrative, which also focused on care, concerned legal aspects for people with dementia. Several governmental investigations discussed the decision-making capacity of people with dementia, guardianship, supported decision-making and the option to delimit selfdetermination by forcing them into care or treatments. This narrative had not yet come to its end. Another contrasting narrative that was not visible in former episodes, sheds light on the heterogeneity of the group, and is articulating the need to consider younger people with dementia, ethnicity and the severity of the disease, when providing support or care.

Hence, in this episode people with dementia were strongly conceptualised in a medical model in terms of having a disease and in having "co-morbidity". The notion of action held sway within the medical model in terms of "quality of care". Within this narrative people with dementia were entitled to citizenship but were disempowered, not least since the relatives were clearer targets for the policy and thus the citizenship. Although they were considered as citizens they were not seen as citizens in their own right, but in relation to other citizens who in some way were also affected by the disease, prominently relatives. It is also evident in this episode that there is a struggle in categorizing citizens into different categories in order to provide the appropriate solutions to the issues regarding them, but also in order to exclude them from, or include them in, some of the citizen content.

\section{Discussion - Shared assumptions and differences}

This paper has explored policy narratives related to people with dementia. In this section we will take a closer look at the meanings and implications. 
Our case illustrates that the policy narratives related to people with dementia have differed in the various episodes. From the beginning of the first episode, people with dementia were either regarded as "ordinary forgetful elderly" or as "mentally deranged patients". These two dominant policy narratives shifted to another when the group started to be conceptualised as the "elderly demented", which lasted until the end of the third episode. However, during the third episode, people with dementia were to a large extent overlooked since the dominant policy narrative concerned the elderly in general. At the end of the third episode and throughout the fourth episode, people with dementia were covered by the dominant narrative of "multi-diseased elderly". In that sense there was a strong medical rationale behind the narrative. However, in contrast to former episodes, dementia was now to a greater extent, something that individuals had, and not necessarily something that was directly related to their identity, as the term people with dementia became more apparent in the documents. Our case also illustrates that policy narratives of people with dementia have been related to differing policy targets, e.g., as "mentally ill”, elderly in general, "demented elderly”, "demented patients”, "frail elderly", "most-diseased elderly", "people with dementia", "younger people with dementia". The latter is a development where people are seen as having an illness or disability rather than becoming and being identified just by their disease. This indicates that dementia-related policies align with, and are relate to, other policy areas. However, in contrast, what is special about dementia as a nature related to the concept of citizenship, is that adult citizens lose cognitive and/or communicative competences in a process that is not always clearly linear or progressive, and is also related to the specific situation. This is especially the case in the early stages of dementia. By that, citizenship of a person in this transitional state of dementia challenges the sometime static notion of citizenship. The transitional state of dementia implies that the concept of citizenship needs to be understood not only as something constantly under negotiation and interpretation and undergoing change, but also that the subjects are not only heterogeneous but have temporal variations when it comes to e.g. memories and competences. Thus, citizens as subjects are not static either, in parallel to what we have argued concerning citizenship, since citizens can be regarded as both competent and incompetent. Moreover, these variations are even more changeable when it comes to people living with dementia (especially in the early stages). 
Even though narratives of people with dementia have varied through the episodes, the consistent construction of people with dementia has to a large extent followed the same line of reasoning; someone who is disturbing or a burden to relatives, to partners, to health-care personnel and other actors, but also to society in general by being "cost-demanding". This politics of dependence seems to be framed as a failure in contrast to that of e.g. a child, or someone who is sick where this human condition is expected to end. In the case of elderly dependence, and particularly in the case of dementia, this dependence is framed as a failure and sometimes even unnatural where the only way forward is backwards, i.e. increased dependency until death. Hence, as shown, people with dementia have been recognised as a differing political problem where various dominant narratives have been established at a national policy level. Also, the policy narratives have to a large extent been linear, which corresponds to the role narratives have, as pointed out by Roe (1994) and Hajer (1993), in stabilising the assumptions in the policy process and conceptualising the world in a similar way. Accordingly, the dominating narrative has closed down opportunities for other stories to be told and other stories to be heard, and thus prohibited narrative expressions for persons or groups (Baldwin 2013). Though there are examples where emerging narratives could challenge the specific dominant narrative, as in the case of the experimental projects of special care facilities in episode \#2, which implied a shift in how people with dementia were constructed in the national policy documents. Despite the group of people with dementia having been negatively framed to a large extent, they have during the episodes been seen as deserving of care, as a group of people in need of care in different forms and also been given such. This at least implies a sense of belonging to a society and some level of solidarity with them as citizens who should be taken care of by the state even though they have not been given the possibility to influence this themselves. There was recognition that the state had responsibility for their well being thus granting them support. The storytelling of the narratives differs in the four episodes. Several documents from the first narrative follow the genre of speeches where talks from symposiums had been written down and took form as national documents. In the latter episodes, the storytelling was more within the genre of formal policy texts. 
Policy narratives tell us something about how the actors understand policies and reality. In the episodes explored, the policy narratives and the way that people with dementia have been framed have not only shaped the understanding of what the problems are, but also inherently how the problems should be handled, such as separating people with dementia from others who are affected by their behaviour. Even if the solution during the last two episodes has tended more and more to home caring, this is often supplemented by day care or other types of support for the carers. Those with dementia were also constructed as a homogenous group, leaving out the individual differences within the group. For example, what was neglected was that there is a vast difference between someone in an early stage, compared to someone in a severe state of dementia. In other words, the same individual has differing capabilities depending on the stage of dementia. Moreover, there are variations in how an individual experiences dementia, also depending on the type of communicative problem and/or the type of cognitive problem. The policy narratives also neglect that people with dementia can belong to differing identities, have different backgrounds, and preferences. It was only in the last episode that a somewhat diverging narrative was emerging, e.g. that people younger than 65 years can have dementia. Accordingly, not only has the notion of action differed, but also the way the policy problem was conceptualised, how people with dementia were categorised, the appropriate solution, and the causality behind this. This follows the role of policy narratives, i.e., as a story that is simplifying the phenomenon they are seeking to steer. The stories are the means that actors use in order to explain their view to others. Hence, policy narratives are related to the power to influence what is regarded as a problem and its appropriate solution. This power was in the hands of the policy makers, which did not include people with dementia or the representatives of people with dementia.

By looking at solutions we get closer to the construction of problems and identifying the narrative. The suggested solutions in the policy narratives and the strategies for solutions have changed over the years: from living in institutions such as nursing homes and mental hospitals to living at home and being taken care of at home, where only those with severe needs could be considered for residential care. In the last episode a written reason for home care as a solution 
was that quality of life would improve in comparison to residential care. Another countering story was that since the public sector was stressed by financial austerity, the welfare state could not be responsible for care to the same extent as before. Also, it is clear that the story of relatives has become more and more dominant. Particularly in the last episodes, there were reports that concentrated specifically on the relatives of people with dementia; to some extent the voice and perspective of the relatives is even more apparent than the voice of those who have dementia. There was also more support aimed at the relatives as they were regarded as important actors concerning the care of people with dementia.

Our case shows that the medical model has dominated the issue of people with dementia over the years. Following this we can see the value of having a critical approach where it becomes revealing, as pointed out by Shore and Wright (1993:3). The powerful actors preferred ways of defining problems and solutions "as if it were the only one possible, while enforcing closure or silence on other ways of thinking and talking”. Alternative stories, e.g. the personhood model and the citizenship model, have to a large extent been silent. However, the personhood model has to some extent followed in the wake of emphasising the personhood of people with disabilities and people with mental illness, which is also visible in the terminology that has changed to people with dementia instead of the "demented". Though clearly the citizenship model is still absent. The reason behind this could be that these stories have been silenced in the political arena of making policies and producing policy documents, which indicates the important aspects of power and participation in the policy process. Researchers advocating these latter models have e.g. less power and are not as strongly legitimised as experts with claimed expert knowledge such as researchers advocating the medical model. A new narrative influenced by a citizenship model is only possible if the policy process becomes open to other ways of thinking and talking, i.e. more inclusive and democratic. However, as mentioned by Schneider and Ingram (2005), policy resistance is more common than policy change, meaning that advocates for the medical model will not easily open up to other claim makers of expertise. Henceforth, this resistance will delay such a change. 
As pointed out by several scholars (Stone 2002; Schneider and Ingram 1993b), policy narratives are an important element when the state influences and legitimises how citizen groups are valued and can be regarded by the state and by other citizens, as a group deserving of certain privileges and, in contrast, be stripped of some privileges. This implies that it is vital for all citizens to have the possibility to participate in and influence the policy process. The construction of a certain group and the dominant perspective will affect both the possibility to influence the issue and shape policies, and the view on problems and their imminent solutions. In addition, the possibility to participate is dependent on the specific group to which a citizen is referred. Our case shows that people with dementia are seldom visible in the policy narratives. This might exclude a group from the content of citizenship, which of course could have been an intentional course of action. The opportunity to influence politics is crucial in belonging to a society and it is apparent that this is not the case when studying the policies surrounding people with dementia, where they by themselves, or through representatives, have had little influence on the policies that have shaped this group of citizens. Nevertheless, the policies have shaped the construction of target groups, which inform that some citizens are valued while others are not as important, which subsequently shapes the meaning of citizenship and its content. The relation between policies and narratives is dynamic and iterative, where the policy is also shaped by the dominant narrative. We can see that emerging narratives could challenge the specific dominant narrative, which implied a shift in how people with dementia were constructed in the national policy documents. This implies that the process in which problems and their imminent solutions become recognised and thereby legitimatised, is not only a struggle over ideas and interests but also, very interestingly, a struggle over policy narratives where various actors compete.

\section{Conclusion}

Based on the findings, we can see that the crafting of the citizens group that is living with dementia has been narrowed, standardized and often negatively framed. Hence, the lack of diversity of the actors involved, including the knowledge that influences and shapes this policy 
area, has had implications on both the framing of the group and the content of their citizenship. An alternative policy narrative could have highlighted the need for people with dementia to have power to influence their own lives as well as the content of their citizenship. This by being regarded as capable citizens as they were before acquiring the dementia label. In parallel with Stone (1984), the conclusion can be drawn that to view dementia in a historical context we can see that "societies have different options, and that they can adapt any choice over the course of time". This study shows the temporal character of people with dementia as a political problem, the implications of policy narratives on people with dementia as a citizen group, and policy narratives as something being crafted rather than shaped by fixed pre-existing "facts". Dementia, and further citizens living with dementia, is never simply a once and for all stabilised meaning. Instead, policy narratives construct reality; they are shapable "social facts" that narrow the vision of a complex problem where the meanings behind them continue to evolve in response to changes. This will also be the case with the narrative of "people with dementia", which presumably will be challenged by another narrative. The differing framings have similarly conceptualised people with dementia, which sheds light on the stabilising role that policy narratives have. The study has illustrated how historically, partly divergent policy narratives shape constructs of target groups, which are necessary for making policies politically and practically feasible. It shows the reason why it is important to have different accounts and different actors involved in the construction of groups. Power is necessary in order to participate and to influence the shaping of policies and the construction of citizenship content and, further, by belonging to a society.

\section{Acknowledgement}

This study was funded by the by the bank of Sweden Tercentenary Foundation as part of the program Dementia: Agency, personhood and everyday life. Grant no. M10-0187:1. 


\section{References}

Alzheimer's Disease International (2012) World Alzheimer's Report 2012 - Overcoming the stigma of dementia. Report.

ASS (Act Concerning Support and Service for Persons with Certain Functional Impairment [Lag om stöd och service till vissa funktionshindrade]). SFS 1993:387.

Atkinson R (2000) Narratives of policy: the construction of urban problems and urban policy in the official discourse of British government 1968-1998. Critical Social Policy 20:211-232.

Baldwin C (2013) Narrative social work: Theory and application. Bristol: Policy press.

Baldwin C (2008) Narrative, citizenship and dementia: The personal and the political. Journal of Aging Studies, 22: 222-228.

Ballenger J.F. (2006) Self, Senility and Alzheimer's disease in modern America. Baltimore: Johns Hopkins University Press.

Bacchi CL (2009). Analysing policy: what's the problem represented to be?. Frenchs Forest, N.S.W.: Pearson

Bartlett R. (2012) The emergent modes of dementia activism. Ageing and Society, 1-22.

Bartlett R, and O'Connor D. (2007) From personhood to citizenship: Broadening the lens for dementia practice and research. Journal of Aging Studies, 21, 107-118.

Behuniak S.M. (2010) Toward a political model of dementia: Power as compassionate care. Journal of Aging Studies, 24, 231-240.

Behuniak S.M. (2011) The living dead? The construction of people with Alzheimer's disease as zombies. Ageing and Society, 31, 01, pp 70-92.

Bosniak L (2006) The citizen and the alien - Dilemmas of contemporary membership. New Jersey: Princeton University Press.

Boswell C, Geddes A and Scholten P (2011) The role of narrative in migration policy-making: A research framework. The British Journal of Politics \& International Relations 13(1): 1-11.

Boyle G (2013) Facilitating decision-making by people with dementia: is spousal support gendered? Journal of Social Welfare and Family Law, 35,2, 227-243.

Boyle G (2011) Early implementation of the Mental Capacity Act 2005 in health and social care. Critical Social Policy, 31(3), 365-387. 
Boyle G (2010) Social policy for people with dementia in England: promoting human rights? Health \& social care in the community, 18(5), 511-9.

Boyle G (2008) The Mental Capacity Act 2005 : promoting the citizenship of people with dementia? Correspondence, 16, 529-537.

Brannelly T (2011) Sustaining citizenship: people with dementia and the phenomenon of social death. Nursing ethics, 18(5), 662-71.

Colebatch HK (2009). Policy. Maidenhead; Open University Press.

Fischer F (2009) Democracy and expertise: reorienting policy inquiry. Oxford: Oxford University Press.

G8 UK (2013) Dementia Summit Decleration. Department of Health. UK, December.

Gaunt D, Öhlander M and Schwartz R (1993) Demenser och demensvård: medicinska, social och kulturella aspekter. Stockholm: Liber utbildning.

Government Bill 1987/88:176 Elderly care in the 90s [Om äldreomsorgen inför 90-talet].

Gilmour J.A, and Brannelly T (2010) Representations of people with dementia - subaltern, person, citizen. Nursing inquiry, 17(3), 240-247.

Hajer MA (1993) Discourse coalitions and the institutionalization of practice: The case of acid rain in Britain. In: Fischer F and Forester J (eds) The Argumentative Turn. Durham, NC: Duke University Press. pp 43-76.

Health and Medical Services Act (HMSA) [Hälso- och sjukvårdslagen]. SFS 182:763.

Hydén L-C (2014) Cutting brussels sprouts: Collaboration involving persons with dementia. Journal of Aging Studies 29(1): 115-123.

Hydén, L-C and Örulv L (2009) Narrative and identity in Alzheimer's disease: A case study, Journal of Aging Studies 23(4): 205-214.

Innes A (2009) Dementia studies. A social science perspective. London: Sage.

IPRHS (The Swedish Institute for Planning and Rationalization of the Health and Social Service [Spri - Sjukvårdens och socialvårdens planerings- och rationaliseringsinstitut]], FCC (Federation of County Councils [Landstingsförbundet]), SALA (Swedish Association of Local Authorities [Svenska kommunförbundet]) and NBHW (National Board of Health and Welfare [Socialstyrelsen]) (1978). Custody of age demented patients - Project plan and basis for discussion [Omhändertagande av åldersdementa patienter - Förslag till slutrapport]. Report. 
Jones MD, Shanahan EA, and McBeth MK (2014) "Introducing the Narrative Policy Framework" in Jones MD, Shanahan EA, and McBeth MK (eds.) The science of stories: Applications of the narrative policy framework in public policy analysis". NewYork: Palgrave Macmillian.

Jones MD, and McBeth MK (2010) Narrative policy Framework: Clear enough to be rong? Policy Studies Journal 38(2): 329-353.

Kelly F, and Innes A (2013) Human rights, citizenship and dementia care nursing. International Journal of Older People Nursing 8(1): 61-70.

Kitwood T (1997) Dementia reconsidered: The person comes first. Buckingham: Open University.

Kymlicka W (2001) Contemporary political philosophy: an introduction. Oxford: Oxford University Press.

Lister R (2003) Citizenship - Feminist perspectives. New York: Palgrave Macmillan

Marshall T. H, and Bottomore TB (1950/1992) Citizenship and social class. London: Pluto Press.

NBHW (National Board of Health and Welfare[Socialstyrelsen]) (2014) Nationell utvärdering Vård och omsorg vid demenssjukdom 2014 - Rekommendationer, bedömningar och sammanfattning.

NBHW (National Board of Health and Welfare[Socialstyrelsen]) (2005) Boende och vårdinsatser för personer med demenssjukdom. Report

NBHW (National Board of Health and Welfare[Socialstyrelsen]) (2000) Elderly commission Final Report.

NBHW (National Board of Health and Welfare[Socialstyrelsen]) (1985) Så var det 1985: Referat från konferens om åldersdemensfrågor 1985-11-22. Stockholm: Garnisonstryckeriet.

NBHW (National Board of Health and Welfare[Socialstyrelsen]) (1980) Ritklinjer för 80-talets psykiatriska vård. Socialstyrelsen anser 1980:2.

Örulv L (2010) Placing the place, and placing oneself within it: (dis)orientation and (dis)continuity in dementia. Dementia: the International Journal of Social Research and Practice, 9:21-44.

Örulv L (2012) Reframing dementia in Swedish self-help group conversations: Constructing citizenship. The International Journal of Self-help and Self-care, 6 (1), 9-41. 
Österholm J H, and Hydén LC (2014) Citizenship as practice: Handling communication problems in encounters between persons with dementia and social workers. Dementia. 0(0). 117.

Österholm J.H, and Samuelsson C (2013) Orally positioning persons with dementia in assessment meetings. Ageing and Society, 1-22.

Roe EM (1992) Applied narrative analysis: The tangency of literary criticism, social science and policy analysis. New Literary History 23(3): 555-581.

Roe EM (1994) Narrative policy analysis: theory and practice. Durham: Duke University Press.

SSA (Social Services Act SSA [Socialtjänstlagen]). SFS 2001:453.

Schneider A, and Ingram H (2005). (red) Deserving and entitled: social constructions and public policy. New York: State university of New York Press

Schneider A, and Ingram H. (1997) Policy design for democracy. Lawrence: University Press of Kansas.

Schneider A, and Ingram H (1993a). Social construction of target populations: Implications for politics and policy. American Political Science Review 87(2): 334-347.

Schneider A, and Ingram H (1993b) Constructing citizenship: The subtle message of policy design. In: Ingram $\mathrm{H}$ and Smith SR (eds) Public policy for democracy. Washington: The Brookings Institutions.

Schön D.A and Rein, M (1994). Frame reflection: Toward the resolution of intractable policy controversies. New York: BasicBooks.

Shore C, and Wright S (eds) (1997) Anthropology of policy: critical perspectives on governance and power. London: Routledge.

Stone DA (1984) The disabled state. Philadelphia: Temple University Press

Stone DA (1989) Causal stories and the formation of policy agenda. Political Science Quarterly 104(2): 281-300.

Stone DA (2002) Policy paradox: The art of political decision making. New York, Norton.

Taghizadeh Larsson A, and Österholm JH (2014) How are decisions on care services for people with dementia made and experienced? A systematic review and qualitative synthesis of recent empirical findings. International Psychogeriatrics. 26(11), 1849-1862. 
Wagenaar H (2011) Meaning in action: interpretation and dialogue in policy analysis. Armonk: Sharpe.

Wilson G (1991) Models of ageing and their relation to policy formation and service provision. Critical Social Policy, 19(1), pp. 37-47.

Yanow D (1995) Built space as story: The policy stories that uildings tell. Policy Studies Journal 23(3): 407-422.

Yanow D (2000) Conducting interpretive policy analysis. London: SAGE.

Yuval-Davis N (2011) The politics of belonging: Intersectional contestations. Los Angeles,

Calif.: Sage

Yuval-Davis N and Werbner P (1999). Women, citizenship and difference. London: Zed Books.

\section{Official texts}

165 policy documents. A list is available upon request. 